\title{
Local Ties in Spatial Equilibrium
}

\author{
Mike Zabek*
}

May 27, 2020

\begin{abstract}
Someone who lives in an economically depressed place was probably born there. And having workers with local ties - who prefer to live in their birthplaces - leads to smaller migration responses in depressed places. Smaller migration responses lead to lower real incomes and make incomes more volatile, a form of hysteresis. Local ties can also persist for generations. Additionally, subsidies to economically depressed places cause smaller distortions, since few people want to move to depressed places. Finally, subsidies to productive places increase aggregate productivity, since they induce more migration.
\end{abstract}

Keywords: Migration, Local Labor Markets, Demography, Growth, Decline JEL Numbers: J61, R23, E62, R58, H31, D61, J11

\footnotetext{
${ }^{*}$ Board of Governors of the Federal Reserve System; Mail Stop I-303; 20th Street and Constitution Avenue N.W.; Washington, DC 20551; mike.zabek@frb.gov. I owe particular thanks to Dominick Bartelme, John Bound, Joshua Hausman, and Matthew Shapiro. Helpful comments were also invaluable, and some of them came from the following people: Martha Bailey, C. Hoyt Bleakley, Charles Brown, Varanya Chaubey, Patrick Coate, David Green, Jeff Larrimore, Nick Moschovakis, Jessica Ott, Claudia Sahm, Robert Schoeni, Christopher Smith, Bryan Stuart, Erin Troland, Robert Willis, and numerous seminar participants. I also am grateful to David Dorn for sharing data and code. Support came from a NICHD center grant (R24 HD041028) to the Population Studies Center at the University of Michigan, through a Rackham Graduate School pre-doctoral grant, and via computation at ARC at the University of Michigan and at the University of Texas at Dallas. The opinions, analysis, and conclusions are those of the author and do not indicate concurrence by the Federal Reserve Board, the Federal Reserve System, the US Census Bureau, anyone associated with these organizations, or anyone else. Results using non public data have been reviewed to ensure that no confidential information is disclosed. Previous versions of this research circulated as "Population growth, decline, and shocks to local labor markets" and "Implications of local ties in spatial equilibrium."
} 


\section{Introduction}

Migration should equalize differences across places, but does it? In models of spatial equilibrium (Rosen, 1979; Roback, 1982), people move until they are indifferent across places. Empirical papers, however, have found that migration responds slowly to economic shocks and that migration rates have been falling in the United States. Many people live near their birthplaces, and so people appear to have local ties - a preference to live near their birthplace.

This paper examines local ties through a Rosen and Roback style model. The model matches the fact that places have very different shares of their populations who live near their birthplace. In the model, economically depressed places have residents who were born nearby and who chose to stay because of their strong local ties. Real wages are lower because population shrinks by less after a series of negative shocks. People also form local ties in new places over time, but local ties to depressed places can persist for generations.

So the paper brings partial equilibrium insights into a general equilibrium model. Several empirical and partial equilibrium studies have found that many workers are reluctant to move (e.g. Kennan and Walker, 2011), but partial equilibrium effects are often undone. It is unclear how low rates of migration among a subset of workers will affect equilibrium outcomes, like population distributions, wages, rents, and welfare. For example, Cadena and Kovak (2016) find that the mobility of immigrants offsets the immobility of natives in equilibrium. In fact, a classic critique of place-based policies designed to stimulate depressed places (Austin, Glaeser and Summers, 2018) is that they induce place-based subsidies that undo increases in real wages by inducing moves into depressed places (Glaeser and Gottlieb, 2008). ${ }^{1}$

Including local ties also explains why people continue to live in economically depressed places - because of local connections. Other studies have claimed that people live in depressed places because inexpensive housing attracts people with low incomes (Notowidigdo, 2011; Ganong and Shoag, 2017; Bilal and Rossi-Hansberg, 2018). However, local ties can also explain why the people who live in depressed

\footnotetext{
${ }^{1}$ The literature on place-based policies also includes Neumark and Simpson (2015); Bilal and Rossi-Hansberg (2018); Chiara Criscuolo, Martin Ralf, Henry G Overman, and John Van Reenen (2019).
} 
places were often born in those places. $^{2}$

Local ties also induce effects that differ from traditional migration costs, as in Rappaport (2004), Kennan and Walker (2011), or Redding and Rossi-Hansberg (2017). Workers with local ties are concentrated in depressed places because local ties, like connections to family and friends, induce people to accept lower real wages to live in their birthplaces. And the accumulation of people with local ties leads to yet lower equilibrium real wages through higher labor supply and housing demand. Low real wages also make depressed places less appealing to outsiders who lack local ties. So outsiders are reluctant to move in, even after positive shocks. The opposite dynamic occurs in growing places - migration acts as a shock absorber that lessens their impact, as in Blanchard and Katz (1992).

My first step in this paper is to empirically document four stylized facts about local ties and economically depressed places. First, the typical American does not move very far - the median U.S. born adult lives within around 100 miles of where they were born. Second, there is a strong correlation between population decline and the share of residents born nearby. On average, a place that has expanded 2.5 percent slower will have 30 percent more of its population born nearby. Third, population losses are rare. Fourth, migration responses are smaller in depressed places where most people were born nearby. ${ }^{3}$

Next, I present a spatial equilibrium model that matches the four facts, formalizes the mechanisms behind them, forecasts long term dynamics, and allows me to study the impacts of place-based subsidies on equilibrium outcomes. I match the stylized facts by including local ties - a parameter describing a worker's preference to live in their birthplace. Workers with strong local ties - high utility payoffs for living in their birthplaces - stay in depressed places that are unattractive to outsiders, leading to lower real wages and smaller migration elasticities. The model shows

\footnotetext{
${ }^{2}$ Two appendices include the dynamics of worker skill, durable housing, and a non-homothetic preference for housing in my framework. My main policy conclusions are equally relevant when I extend the model to include both features. And my empirical results survive robustness checks for several alternative hypotheses.

${ }^{3}$ These four facts do not appear to be widely known, but it is unlikely that I am the first to point them out. For example, Glaeser and Gyourko (2005) also document that population losses are rare and several authors have noted that people are quite unlikely to move (Kennan and Walker, 2011; Diamond, 2016).
} 
that smaller migration elasticities reflect the preferences of outsiders as much as the preferences of locals. I also include a law of motion for workers' birthplaces that leads the model to converge to a steady state. But convergence takes generations. In the steady state workers' local ties are a function of economic fundamentals like productivity.

The model overturns the simple story of equilibrium dynamics undoing the benefits of place-based policies. Place-based subsidies can actually be efficacious, but for different purposes in different places. Subsidies to high ties, depressed places decrease geographic inequality. Subsidizing a depressed place transfers income without changing population by very much, so it leads to only a small decrease in aggregate productivity. Subsidies to low ties, productive places increase aggregate productivity. Subsidizing a low ties place moves more people because of a higher migration elasticity. Migration to a productive, low ties place increases aggregate productivity and leads to higher wages in other places. Population reallocations also lead future generations to form ties to more productive places.

The results build on mostly empirical and partial equilibrium studies that highlight mechanisms leading to local ties, along with other studies that find small migration responses to large shocks. One literature focuses on how social networks influence people's decisions to migrate (Munshi (2003); Yannay Spitzer (2015); Black et al. (2015)). Other studies have documented reasons why people could have local ties that lead them to live near where they were born. Workers receive some labor market benefits when they live close to their parents (Kaplan, 2012; Kramarz and Skans, 2014; Coate, Krolikowski and Zabek, 2019) and workers also appear to move closer to their birthplaces after job displacements (Huttunen, Møen and Salvanes, 2018). But young people can also earn more when they move away from their birthplaces (Shoag and Carollo, 2016; Nakamura, Sigurdsson and Steinsson, 2016), implying that many people have a strong preference to remain. Many recent studies have also found that migration is unusually slow given high returns (Bound and Holzer, 2000; Dao, Furceri and Loungani, 2017; Yagan, 2017; Chetty and Hendren, 2018). Finally, several studies also find that frictions in the housing market have increased geographic inequality (Glaeser and Gyourko, 2005; Notowidigdo, 
2011; Hsieh and Moretti, 2015; Ganong and Shoag, 2017). ${ }^{4}$

The framework shows general equilibrium effects of including workers with differing migration elasticities. Most notably, Cadena and Kovak (2016) and Albert and Monras (2018) show that immigrants are more mobile than natives. And Mangum and Coate (2018) show that changes in people's amount of history in places mirror declines in migration rates. This paper enriches those studies by showing that productivity increases lead mobile people to concentrate in places with high real wages.

The paper also relates to others that connect equilibrium models to more realistic microeconomic foundations. Related papers examine the impacts of local labor market boundaries (Manning and Petrongolo, 2017; Green, Morissette and Sand, 2017), introduce frictional unemployment into spatial equilibrium (Kline and Moretti, 2013; Beaudry, Green and Sand, 2014), calculate indirect effects of local shocks on other places (Hornbeck and Moretti, 2018), and add additional micro foundations to spatial equilibrium models (Coen-Pirani, 2010; Kennan and Walker, 2011; Davis, Fisher and Veracierto, 2013; Gregory, 2013; Monras, 2015; Diamond, 2016; Fu and Gregory, 2018).

The paper proceeds as follows. First, I document four empirical facts about economically depressed places. Second, I embed the four facts in an equilibrium model. Third, I show how places with high levels of local ties have lower real wages and I use the model to analyze place-based subsidies. I conclude with recommendations for policy and further research.

\section{Four Empirical Facts}

\section{Data}

The analyses use U.S. Census long form and American Community Survey (ACS) data provided via IPUMS (Ruggles et al., 2010), unless otherwise noted. The Decennial Census and ACS contain data on wages, rents, labor force status, and birth-

\footnotetext{
${ }^{4}$ Appendices D and $\mathrm{F}$ show how literatures on differential migration elasticities by worker skill and frictions in the housing market are consistent with the main results of the paper.
} 
places - equilibrium outcomes of interest. Additionally, the data is from three percent of the population in the ACS and five percent of the population in the Census.

I measure outcomes for adults in Commuting Zones (CZs, Tolbert and Sizer (1996)) over roughly ten year intervals. I include only adults 22 to 64 because of my focus on workers, and I also use labor supply weights so my statistics on wages reflect wages per hour worked. I use CZs because they cover the entire Continental United States, including rural areas, and because they reflect places where workers live and work. Finally, focusing on economic outcomes in roughly ten year increments allows me to abstract from more short term moving costs. Appendix A provides additional data on the sample and dataset construction.

I proxy for local ties by computing the share of workers living in their birthplace. Birthplaces perform important administrative functions - determining citizenship and social security numbers - and so many data sources include them. They also predict people's subsequent location quite well, particularly in childhood, and so they have been widely used by researches (e.g. Kearney and Levine (2015); Stuart (2017)). I use birth states, because they are the smallest geography available. Appendix D provides some robustness exercises using alternative measures of local ties, and A discusses why the lack of more detailed birthplaces is unlikely to overturn my main conclusions.

\section{Facts}

\section{Most People Live Close to their Birthplaces}

Half of U.S. born adults live within 50 miles of their birth place. Figure 1 shows this through an adaptive kernel cumulative density function of people's distances from their birthplace in the 2000 Census..$^{5}$ The relationship is roughly log-linear. About a quarter of adults live within ten miles of their birth places, about 60 percent live within 100 miles, and about 20 percent live more than 500 miles away.

More broadly, Figure 1 shows shows that migrants are a small, select group. Most

\footnotetext{
${ }^{5}$ Distances are from census tracts in the 2000 Census complete count and the population weighted center of the person's birth county in records maintained by the Social Security Administration. Birth counties are constructed by matching text describing birthplaces, usually from birth certificates. Stuart (2017) provides more details.
} 
people live close to their birthplaces. ${ }^{6}$ And the fact that the group of migrants is so small will influence the analysis that follows in two ways. First, this small group is quite concentrated in places with low ties. Second, the tastes of this small group of migrants will determine how many people will move in or out of a place after shocks. Places that are unattractive to migrants will draw fewer after future shocks.

Figure 1: Distances Adults Live from their Birthplaces

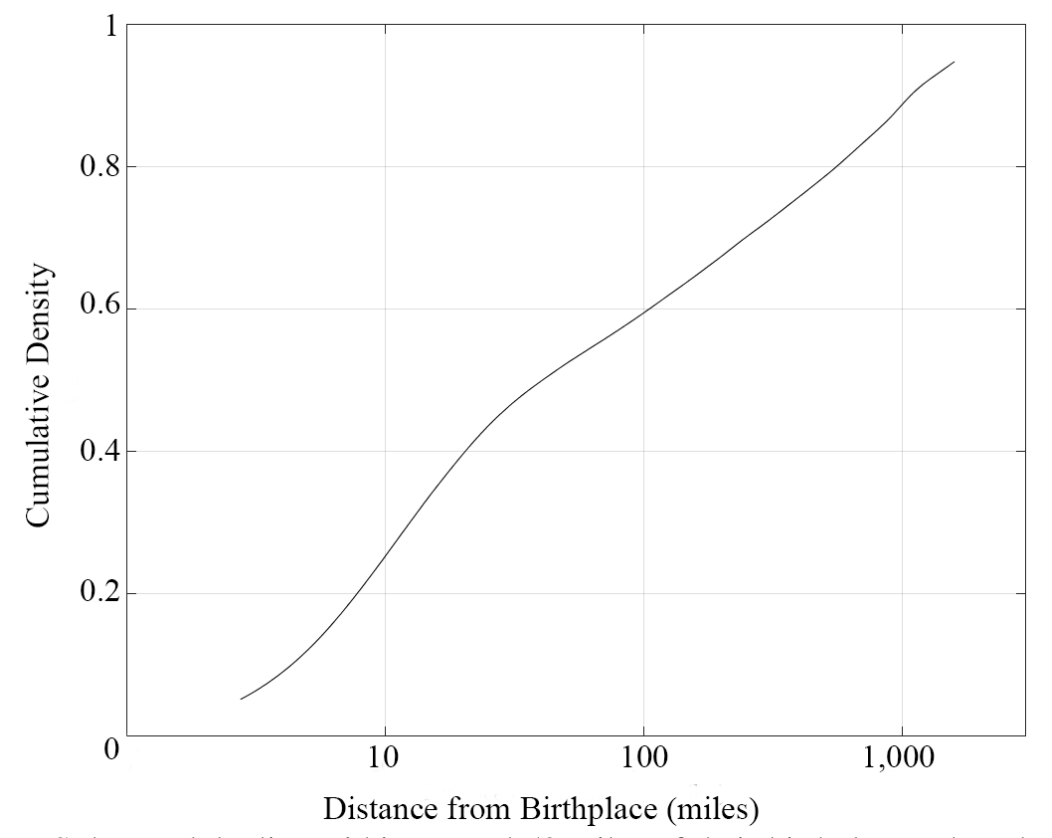

Note: Most U.S. born adults live within around 50 miles of their birthplaces, though a substantial minority live very far from their birthplace. Plotted is an adaptive kernel density distances people from birthplaces based on 2000 Census complete count data linked to administrative data from the Social Security Administration (Stuart, 2018).

\section{Migrants Concentrate in Growing Places}

Inter-state migrants are highly concentrated in particular parts of the U.S., as shown in Figure 2. The differences between the light and dark shades are quite large - the dark shade for Syracuse, New York, implies that 80 percent of residents were born in the same state, while the light shade for Denver, Colorado, implies that around 30 percent of residents were born in the same state. The most obvious pattern is

\footnotetext{
${ }^{6}$ Mobility varies with demographics, most notably by education, but 40 percent of college educated adults still live in their state of birth (Bartik, 2009).
} 
higher shares of migrants in the west, and lower shares of migrants in the east, with the exception of the Atlantic seaboard. The darkest shades cover Appalachia, the Rustbelt, and the Mississippi Delta - places many consider economically depressed.

Figure 2: Shares of Residents Born in the Same State

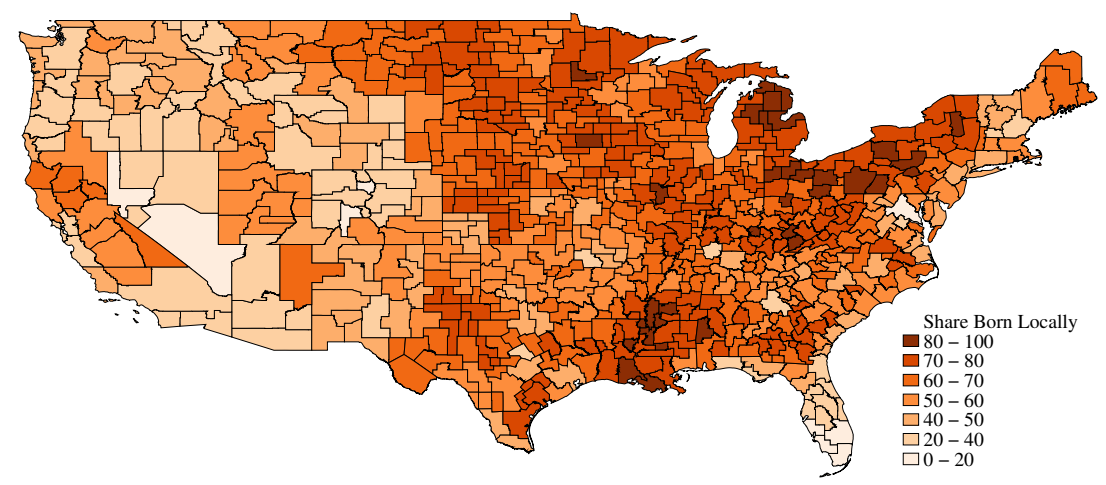

Note: Growing CZs in the west and south have much lower shares of their populations born locally than economically depressed areas in Appalachia, the Upper Midwest, and the Mississippi Delta. Plotted is the share of adults living in their state of birth for all CZs in the Continental US. Data are from the 2006-2008 ACS three year estimates.

Economic distress leads to stronger local ties. To see this, consider the experiences of Dayton, Ohio, and Dallas, Texas. Figure 3 shows the population in each CZ broken out by people who were born in the same state (born locally) and people who were born anywhere else (born outside, which includes the foreign born). In 1970, Dallas and Dayton had similar populations and two thirds of people were born locally in each area. But Dallas has grown much faster since 1980 because outsiders have moved in. In 2008, less than half of Dallas' population was born in Texas. Dayton still contains mostly people who were born in Ohio.

This link between outsiders moving in and increases in population applies more generally. The plot in Panel A of Figure 4 shows the robust negative relationship between population growth from 1980 to 2008 on the horizontal axis and the percentage of residents who were born locally on the vertical axis, measured in 2008. Approximately 30 percent less of the population will have been born in the same state in a CZ whose population increased 100 percent more between 1980 to 2008.

Places where people have higher levels of local ties also show signs of economic distress. Table 1 presents summary statistics broken out for places with high ties - 
Figure 3: Population Changes in Two Cities

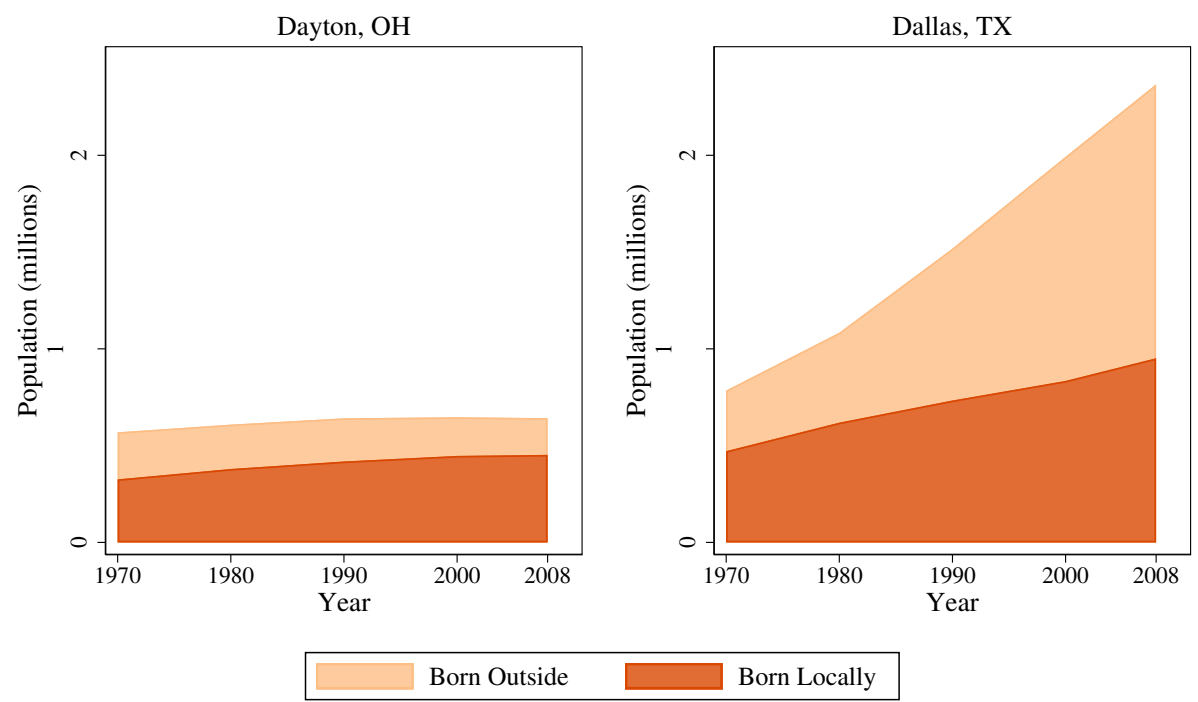

Note: Dallas grew faster than Dayton by attracting people who were born outside of the state. Plotted is population by year, broken out by adults born in and outside of each state. Data are from the Decennial Census and 2006-2008 ACS estimates.

places where more than 60 percent of workers born were locally. Places with high ties have smaller populations, lower wages, lower rents, lower shares of college graduates, slightly older populations, and lower shares of foreign born residents. They also have similar rates of labor force participation and unemployment, despite having lower wages and lower shares of college graduates. ${ }^{7}$

${ }^{7}$ Appendices D and $\mathrm{F}$ assess robustness of other empirical results and of the modeling framework to other differences. Empirically, the results are not sensitive to allowing differing responses by an area's age composition, the share of the population that is college educated, the share of the population working at baseline, two measures of rents in the spirit of Glaeser and Gyourko (2005), and other robustness exercises. The model results are equally meaningful when I extend the model to include a concave housing supply curve, heterogeneous housing expenditure shares, and imperfectly substitutable worker skill levels. 
Figure 4: Population Changes and Local Ties

Panel A: Percentage Born in State

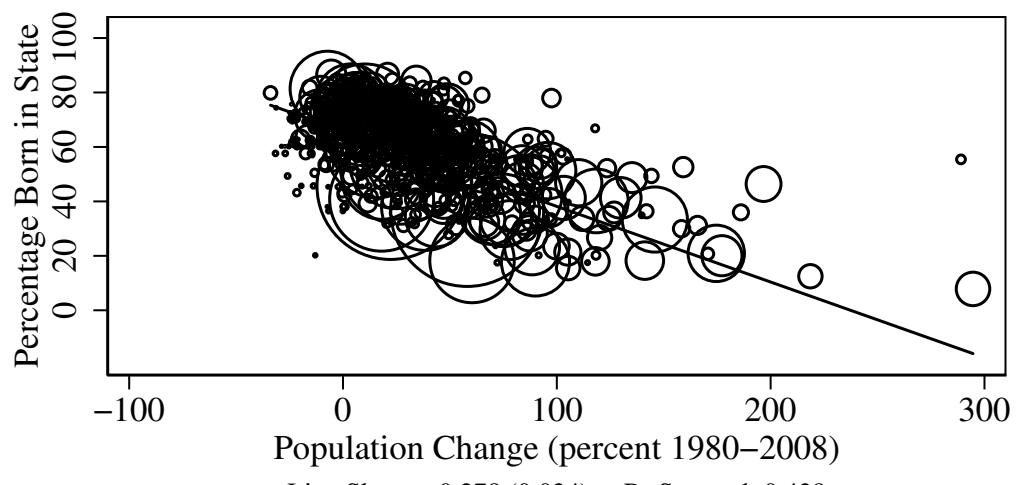

Line Slope: -0.278 (0.034) R-Squared: 0.438

Panel B: Density

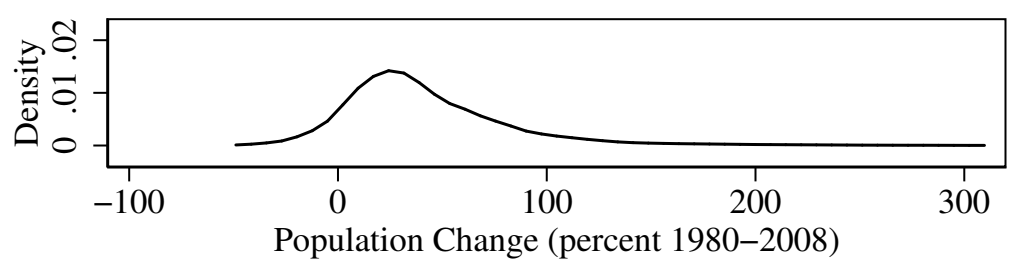

Note: There is a negative relationship between population changes and the share of population born in state. Population growth is also right skewed, and long term population decline is rare. The top plot is of population changes and the proportion of residents born nearby. Each circle is a CZ with a radius proportional to adult population in 1980. The regression line is from a weighted least squares regression. The bottom plot is an adaptive kernel density of population changes from 1980 to 2008, weighted by initial population and using an Epanechnikov kernel with a bandwidth of 15. Data are from the 1980 census and 2006-2008 ACS, and Table A.2 lists the largest CZs. 
Table 1: Summary Statistics

\begin{tabular}{lrrrr}
\hline \hline & & & Low & High \\
& Mean & StD & Ties & Ties \\
\hline Population (thousands) & 188 & 532 & 326 & 123 \\
Percent in labor force & 74.8 & 5.4 & 74.6 & 74.9 \\
Real wages (hourly \$) & 15.6 & 2.2 & 16.6 & 15.2 \\
Real rents (monthly \$) & 524 & 117 & 605 & 487 \\
& & & & \\
Percent locals & 64.4 & 15.8 & 45.0 & 73.3 \\
Average time in house (yrs) & 9.0 & 1.4 & 7.7 & 9.5 \\
Percent unemployed & 3.8 & 1.3 & 3.9 & 3.8 \\
Percent foreign born & 4.2 & 5.4 & 7.8 & 2.5 \\
Percent migrated & 11.3 & 5.4 & 16.7 & 8.8 \\
Percent college educated & 42.7 & 11.3 & 49.2 & 39.7 \\
Percent under 35 & 37.9 & 5.7 & 38.5 & 37.7 \\
Percent over 50 & 25.9 & 3.1 & 24.8 & 26.4 \\
& & & & \\
Bartik shifter (percent) & -9.5 & 22.5 & -11.2 & -8.6 \\
Chinese imports in 1990s & -1.2 & 1.8 & -0.7 & -1.4 \\
Chinese imports in 2000s & -2.6 & 3.0 & -1.8 & -3.1 \\
\hline \hline
\end{tabular}

Note: The tables show unweighted summary statistics for the sample of 722 continental CZs for 1980, 1990, and 2000. The first columns show the mean and standard deviation among all CZs, the next two show means for areas with low and high ties (above or below 60 percent locals). The Bartik and Chinese import variables are measured as changes in the periods when they are used for the regressions below.

\section{Population Losses are Rare}

Several CZs have doubled in size over the last thirty years, but it is rare for one to shrink. It is exceptionally rare for a $\mathrm{CZ}$ to lose more than a quarter of its population. The adaptive kernel density in Panel B of Figure 4 shows that the distribution of population changes is right skewed and that population losses are rare.

Many researchers have focused on the right tail of this distribution, including many papers focusing on Zipf's law (Gabaix, 1999); fewer researchers have focused on the lack of mass below zero. The lack of mass below zero suggests that some friction prevents populations from shrinking by too much. One possibility is the presence of local ties. Another, explored in Glaeser and Gyourko (2005), is that the 
durability of the housing stock makes housing so inexpensive that people are still willing to live in depressed places. I explore how local ties and durable housing could interact in Appendix F.

\section{Smaller Migration Responses in Depressed Places}

Migration responses are smaller in depressed places where more people were born nearby. I demonstrate these smaller migration responses using two shift-share approaches to compare the response of population and participation to labor demand shocks. Labor demand shocks to depressed places where people were born nearby lead to large changes in labor force participation and small changes in population. Large participation responses accompanied by small population responses imply low migration elasticities - something I show in Appendix B.

\section{Labor Demand Shocks}

The first shift-share approach is a Bartik (1991) shifter, which I construct for the 1980s. For place $j$ the Bartik shifter is a weighted average of changes in industry level employment $(L)$ elsewhere $(-j)$ from 1980 to 1990 . The weights are the industry's initial share of employment in place $j$. The last rows of Table 1 shows that the shifters had a wide spread in terms of predicted percentage point changes in employment, but similar average values in places with differing local ties.

$$
\Delta \hat{L}_{j, 1990}=\sum_{i \in \text { ind }}\left(\frac{\Delta L_{i,-j, 1990}}{L_{i,-j, 1980}}\right) \frac{L_{i, j, 1980}}{L_{j, 1980}}
$$

The second shift-share approach uses increases in Chinese imports in the 1990s and early 2000s, owing to Autor, Dorn and Hanson (2013). The equation is quite similar. For area $j$ from period $t-1$ to $t$, the trade shifter is a weighted average of changes in Chinese imports to the US, where the weights are the industry's initial share of employment in place $j . \Delta M_{i, t}$ measures changes in imports from China in thousands of dollars. I multiply it by negative one to match the sign of the other approach. Table 1 shows that these shocks had larger impacts on high ties places. ${ }^{8}$

\footnotetext{
${ }^{8}$ Autor, Dorn and Hanson (2013) use slightly different notation.
} 


$$
\Delta \hat{L}_{j, t}=\sum_{i \in \text { ind }}\left(\frac{-\Delta M_{i, t}}{L_{i, t-1}}\right) \frac{L_{i, j, t-1}}{L_{j, t-1}}
$$

The two approaches rely on the aggregate changes being large and unrelated to unobservable changes in labor supply in areas that were the most affected (Borusyak, Hull and Jaravel, 2018; Goldsmith-Pinkham, Sorkin and Swift, 2018). Changes in trade patterns, exchange rates, and capital investment greatly affected particular industries in the early 1980s. These changes were not directly related to labor supply factors. And the emergence of Chinese import competition was similarly driven by factors unrelated to local labor supply behavior. The factors were also outside of the US, since I follow Autor, Dorn and Hanson (2013) in instrumenting using Chinese import penetration in other countries. As (Borusyak, Hull and Jaravel, 2018) show, industry employment shares need not be exogenous. ${ }^{9}$

$$
\Delta y_{j, t}=\alpha_{t}+\left(\beta_{L}\left(1-\mathbf{1}_{H}\right)+\beta_{H} \mathbf{1}_{H}\right) \Delta \hat{L}_{j, t}+\gamma_{H} \mathbf{1}_{H}+\gamma_{X} X_{j, t-1}+\epsilon_{j, t}
$$

I estimate the effects of changes in labor demand on changes in the population, in the labor force participation ratio, in residualized wages, and in local rents. ${ }^{10}$ And I allow the effect to differ by levels of local ties. Roughly half of all places have high levels of local ties, which I define as having more than 60 percent of workers initially born in state $\left(\mathbf{1}_{H}=1\right)$. The labor demand shifter is denoted $\Delta \hat{L}_{j, t}$, so the $\beta$ coefficients show the effect of these shocks for the specified subset of local labor markets. Estimating the equation in first differences controls for time invariant effects, and I also include other controls to pick up differences in trends. The controls include time dummies $\left(\alpha_{t}\right)$ and demographic characteristics of individual local areas $(X) .{ }^{11}$ Standard errors are clustered by the state containing

\footnotetext{
${ }^{9}$ Several critiques in Borusyak, Hull and Jaravel (2018) focus the interpretation of coefficients as changes due in international trade. They do not apply to this interpretation - as only a labor demand shifter.

${ }^{10}$ Residualized wages come from regressing log wages on four categories of education, gender, an indicator for being Black, and an indicator for being foreign born. Regressions use labor supply weights and are estimated separately in each year.

${ }^{11}$ In addition to dummy variables for each bin of local labor markets, I control for the share of working age adults outside the labor force, unemployed, foreign born, having entered the state in the
} 
the plurality of the CZ's population.

Results

Migration responses are smaller in places with higher levels of local ties. In Panel A of Table 2, a one percentage point predicted increase in employment in an area with high local ties increases the population by a statistically insignificant 0.4 percent. And the population increase of almost 1.5 percent in a low ties area is large relative to a one percent predicted increase in employment. The one percentage point difference between population responses in high and low ties places is also statistically significant. There are no statistically significant differences in any of the other outcomes. The results are especially noisy in terms of wages, however, so I am unable to rule out large responses. The lack of other responses in low ties places supports the finding of Blanchard and Katz (1992) that places can respond to shocks through changes in populations as opposed to wages or other labor supply margins. I do not find evidence that differing housing supply elasticities drive the different population responses, since rents respond similarly.

Places with higher local ties adjust in terms of wages and labor force participation, as opposed to population. Panel B of Table 2 shows that a $\$ 1,000$ per worker decrease in import competition from Chinese firms in a lower ties place leads to a 0.8 percent increase in population and a statistically insignificant change in a higher ties place. Instead, high ties places see labor force participation increase by 0.8 percentage points and wages increase by around 0.6 percent. High and low ties places also experience similar increases in rents. ${ }^{12}$

Overall, migration elasticities are smaller in places where people have stronger local ties. Estimates in Appendix $\mathrm{C}$ suggest that they are an order of magnitude lower in places with high levels of local ties -0.1 versus around 1 .

past five years, and the share of adults who are under 35 and 50 to 64 . Appendix D shows further robustness for these variables.

${ }^{12}$ Panel B also keeps with the finding of very large non-participation responses in Autor, Dorn and Hanson (2013). The larger non-particpation responses support a literature on both declining recent migration as well as a more vibrant non-participation margin since the 1980s because of the entry of women and the growing importance of male labor force non-participation. Finally, one additional explanation for their finding of large non-participation responses is to combine the finding of small population and robust non-participation responses in high ties places with the fact that Chinese import shocks affected high ties places more acutely (Table 1). 
Table 2: Labor Demand Shocks by Share Born Locally

Panel A: Bartik Shifter in the 1980s

\begin{tabular}{lcccc}
\hline \hline & Population & Participation & Wages & Rents \\
\hline Bartik: High ties & 0.37 & 0.08 & 0.29 & 0.29 \\
& $(0.22)$ & $(0.03)$ & $(0.21)$ & $(0.25)$ \\
Bartik: Low ties & 1.46 & 0.05 & 0.26 & 0.25 \\
& $(0.39)$ & $(0.03)$ & $(0.24)$ & $(0.33)$ \\
High ties & 15.40 & -0.42 & -0.35 & -1.22 \\
& $(5.32)$ & $(0.45)$ & $(4.40)$ & $(5.52)$ \\
\hline P-val: No diff & 0.01 & 0.29 & 0.92 & 0.93 \\
$R^{2}$ & 0.58 & 0.36 & 0.35 & 0.54 \\
Observations & & 722 & & \\
\hline \hline
\end{tabular}

Panel B: Chinese Import Shifter in the 1990s and Early 2000s

\begin{tabular}{lcccc}
\hline \hline & Population & Participation & Wages & Rents \\
\hline Imports: High ties & -0.10 & 0.78 & 0.64 & 1.19 \\
& $(0.30)$ & $(0.17)$ & $(0.18)$ & $(0.57)$ \\
Imports: Low ties & 0.78 & -0.01 & 0.09 & 1.37 \\
& $(0.38)$ & $(0.10)$ & $(0.25)$ & $(0.28)$ \\
High ties & -5.42 & 2.17 & 0.36 & -2.76 \\
& $(1.58)$ & $(0.41)$ & $(0.89)$ & $(1.81)$ \\
\hline P-val: No diff & 0.02 & 0.00 & 0.08 & 0.78 \\
$R^{2}$ & 0.47 & 0.54 & 0.12 & 0.18 \\
Observations & & 1444 & & \\
\hline \hline
\end{tabular}

Note: Migration responses are smaller in places with higher levels of local ties since labor demand shocks change labor force participation rates and wages, not population - as in low ties places. Panel A reports OLS regression coefficients from regressing each outcome on predicted percentage changes in employment and Panel B reports two stage least squares estimates using Chinese trade with other countries to instrument for Chinese imports to the U.S. in thousands of dollars per worker. High ties means having 60 percent or more residents born in state. P-values are from Wald tests that effects are equal everywhere. Population is changes in log population 22 to 64, participation is the labor force participation rate, wages are residualized log wages, and rents are log gross rents. The unit of observation is a $\mathrm{CZ}$ weighted by initial population. Controls are: the share of working age adults outside the labor force, unemployed, with a college education, foreign born, having migrated in the past five years, adults under 35, and adults 50 to 64 . Standard errors in parentheses are clustered by state. Data are from the 1980, 1990, and 2000 Census and the ACS. 
Robustness checks in Appendix D also show that the results are not driven by other variables, by proxy for local ties, or the 60 percent cutoff. I investigate other variables by including measures of age composition, educational attainment, labor force attachment, and local housing markets dynamics. Interactions of each variable with labor demand shifters do not change the main conclusions. Nor does using an alternative measure of local ties. The results are also robust to using a triple difference specification without the 60 percent cutoff.

\section{Model}

This section presents a Rosen and Roback style model of spatial equilibrium that incorporates local ties - preferring to live in one's birthplace. Incorporating local ties allows me to match the facts above - that people do not move very far, that residents of depressed places have strong local ties, that population declines are rare, and that migration responses are smaller in depressed places.

The model allows me to analyze how local ties affect the equilibrium. An increase in a place's local ties leads real incomes to fall by more, since people with local ties accept low real incomes. And the drop in real incomes lowers migration responses by making the place less attractive to workers without local ties.

In the long run, the model enters a steady state where local ties have no influence. Steady state occurs because people with local ties to depressed places eventually die. Children are born with ties to productive places, since births are proportionate to current populations. Permanent subsidies to depressed places are undesirable, since they keep populations in depressed places permanently. But a subsidy that slowly declines will have a only small effect since convergence is so slow.

Setting and agents The model is in spatial equilibrium across many places indexed by $j$. Workers can freely move in each period, but they have ties to their birthplace indexed by $k$. I use $i$ to index the magnitude of local ties - utility payoffs from living in one's birthplace. Places have amenity values $\left(A_{j}\right)$ and wages $\left(w_{j}\right)$ that apply to both locals and outsiders. Local firms set wages based on market conditions, which includes the level of local productivity $\left(\theta_{j}\right)$. Landlords set rents 
$\left(r_{j}\right)$ based on an imperfectly elastic supply of housing. Net subsidies to particular places $\left(g_{j}\right)$ balance the government's budget.

\section{Workers}

Workers choose where to live based on their consumption in the place as well as the amenity value that they attach to living in the place, which varies based on the worker's birth place. Specifically, a worker of type $i$, living in place $j$, and with birth place $k$, has Cobb-Douglas utility in a consumption good $\left(c_{j}\right)$ and local housing $\left(h_{j}\right)$ with a housing share parameter of $\alpha^{H}$. The worker also values a local amenity $\left(A_{j}\right)$ and a type I extreme value distributed error term $\left(\xi_{i j}\right)$.

$$
u_{i j k}=\left(1-\alpha^{H}\right) \ln \left(c_{j}\right)+\alpha^{H} \ln \left(h_{j}\right)+A_{j}+\mathbb{1}(k=j) \mu_{i}+\xi_{i j}
$$

A worker's local tie to $k$ is the $\mu_{i}$ term. For tractability, I assume that the distribution $\mu_{i}$ is normal and identical in all places. So people are no more attached to depressed places conditional on being born there. Instead, aggregate differences in local ties emerge from workers chosing to live in depressed places.

The budget constraint in place $j$ balances local wages $w_{j}$, local rents $r_{j}$, and a net subsidy from the government $g_{j}$. I include only one skill level here, but Appendix F shows that the main points also apply to an extension with different worker skill levels. I also assume that workers inelastically supply labor, following the literature on spatial equilibrium. ${ }^{13}$

$$
c_{j}+r_{j} h_{j}=w_{j}+g_{j}
$$

The setup yields a log linear indirect utility function that is a function of the prices, subsidies, amenities, local ties, and other idiosyncratic factors $\left(\xi_{i j}\right)$. I separate common from idiosyncratic factors by denote the prices, subsidies, and amenities that apply to all residents' utilities with real incomes, $\omega_{j}$.

\footnotetext{
${ }^{13}$ Appendix $\mathrm{C}$ provides a simple way to connect a wide class of models, including this one, to the empirical results that include employment to population ratios.
} 


$$
\begin{aligned}
& u_{i j k}=\ln \left(w_{j}+g_{j}\right)-\alpha^{H} \ln \left(r_{j}\right)+A_{j}+\mu_{i} \mathbb{1}(k=j)+\xi_{i j} \\
& u_{i j k}=\omega_{j}+\mu_{i} \mathbb{1}(k=j)+\xi_{i j}
\end{aligned}
$$

The likelihood that a worker lives in $j, \psi_{i j k}$, is familiar and helps to determine migration elasticity in the model. It increases in $\omega_{j}$ and $\mu_{i}$. It also varies with the spread of the type I extreme value term $\left(\sigma_{\xi}\right)$.

$$
\psi_{i j k}=\frac{\exp \left(\frac{\omega_{j}+\mu_{i} \mathbb{1}(k=j)}{\sigma_{\xi}}\right)}{\sum_{j^{\prime} \in J} \exp \left(\frac{\omega_{j^{\prime}}+\mu_{i} \mathbb{1}\left(k=j^{\prime}\right)}{\sigma_{\xi}}\right)}
$$

\section{Production}

Local good varieties are produced by a representative, perfectly competitive local firm. The local firm uses a Cobb-Douglas production function to combine capital $\left(K_{j}\right)$, supplied at interest rate $\rho$ with local labor $\left(N_{j}\right)$ to produce $Y_{j}$ of the local good. ${ }^{14}$ The place has a specific productivity $\theta_{j}$ that is effectively a proxy for the place's economic prospects. The $\alpha_{Y}$ parameter is the same everywhere.

$$
Y_{j}=\theta_{j} K_{j}^{\alpha^{Y}} N_{j}^{1-\alpha^{Y}}
$$

A perfectly competitive national firm produces consumption goods out of local goods using a CES aggregator. It buys each local good at a price of $p_{j}$, to combine them into the numeraire consumption good $Y$. The Armington elasticity (of substitution) between local goods is $\eta^{Y}$ and $\phi_{j}$ is a demand shifter for each local good.

$$
Y=\left(\sum_{j^{\prime} \in J} \phi_{j^{\prime}}^{\frac{1}{\eta^{Y}}}\left(Y_{j^{\prime}}\right)^{\frac{\eta^{Y}-1}{\eta^{Y}}}\right)^{\frac{\eta^{Y}}{\eta^{Y}-1}}
$$

\footnotetext{
${ }^{14}$ The number of workers is denoted by $N$. So $N_{j}$ workers live in place $j, N_{j k}$ workers who live in $j$ were born in $k$, and $N_{i k j}$ workers are of type $i$, born in $k$, and living in $j$.
} 


\section{Housing}

As places grow, housing becomes more expensive. Local rents, $r_{j}$ depend on demand from workers and an upward sloping housing supply curve with elasticity $\eta^{H}$.

$$
H_{j}^{S}=r_{j}^{\eta^{H}}
$$

\section{The Distribution of Local Ties Across Places}

The models' equilibrium - presented in Appendix E - is conditional on a distribution of local ties and evolves based on changes in productivity and amenities. Mechanically, the model begins at a steady state where equal fractions of workers in all places were born nearby. I then change the local productivity terms $\left(\theta_{j}\right)$ to create a distribution of places where different fractions of workers were born nearby.

Figure 5 shows model simulations of how large, one time productivity changes lead to changes in both total population and the share of people born locally. ${ }^{15}$ The $\mathrm{x}$ axis shows productivity shocks, while the $\mathrm{y}$ axis shows population broken out by where workers were born and normalized to one in a place with no change in productivity. Positive productivity shocks lead to increases in population through increases in the number of outsiders, while negative productivity shocks lead to a concentration of locals and smaller decreases in population, since the place becomes unappealing to outsiders.

\footnotetext{
${ }^{15}$ The simulations use the model's baseline calibration, which I explain below.
} 
Figure 5: Population after Productivity Changes in the Model

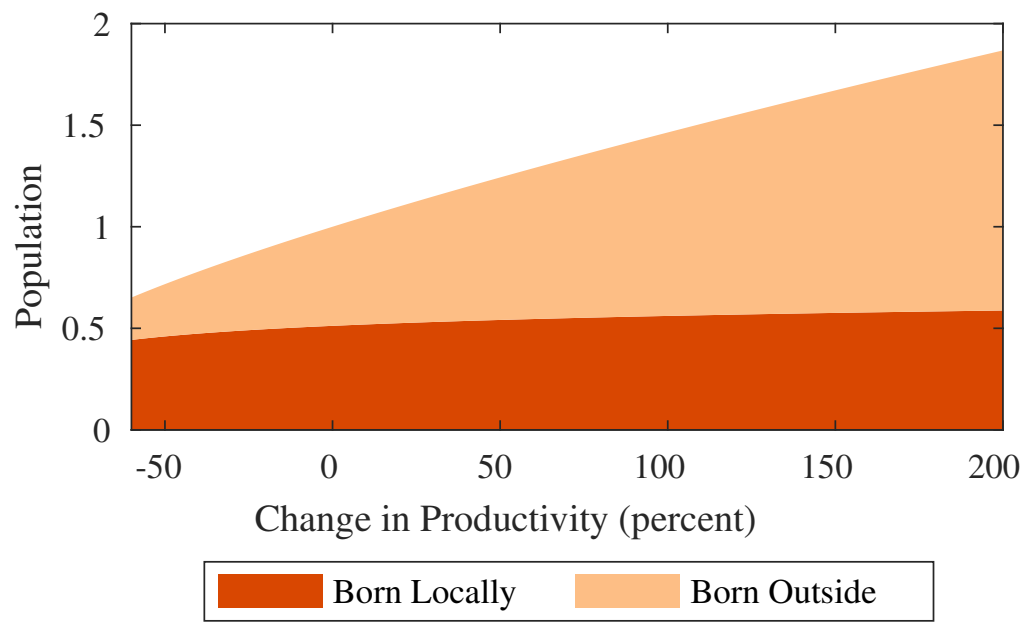

Note: Positive productivity increase population by attracting outsiders, while negative productivity shocks lead to a concentration of locals in the model. The y axis shows total population broken out by birthplaces, normalized to 100 for no change in productivity. The $\mathrm{x}$ axis shows percentage changes in productivity, $\theta_{j}$.

Figure 5 also shows that the model matches an empirical fact. Places that had negative productivity shocks have a similar number of locals, but a much smaller number of outsiders. So migrants concentrate in growing places.

I use one time changes in productivity to mimic economic decline over a decade or two. Since population changes are quite persistent (Blanchard and Katz, 1992), cumulative changes can be quite large over ten to twenty years.

I also include a law of motion for local ties that allows them to change over time while keeping total population stable. The essential assumptions are that new ties are formed proportionate to population and that new workers receive a local tie to their birthplace that comes from the same distribution for all birth places.

The number of workers born in place $k$ in the next period is equal to the number of workers with ties last period who survive from last period plus workers born this period. I assume that workers have a fixed and unchanging likelihood of dying each period $\left(s_{D}\right)$ so $N_{k}\left(1-s_{D}\right)$ workers survive with a tie to place $k$. New workers are born according to the current distribution of population. So $\sum_{k^{\prime}} N_{k k^{\prime}} \frac{s_{D}}{1+s_{F}}$ workers are born - the first term is the current population and the second term is a scaling parameter to keep both a constant population and a constant share of the population 
being foreign born. ${ }^{16}$

$$
N_{k}^{\prime}=N_{k}\left(1-s_{D}\right)+\sum_{k^{\prime}} N_{k k^{\prime}} \frac{s_{D}}{1+s_{F}}
$$

In the long run, the law of motion leads to the steady state below. It is straightforward to show that it is stable and unique.

$$
N_{k}=\frac{\sum_{k^{\prime}} N_{k k^{\prime}}}{1+s_{F}}
$$

\section{Calibration}

The objective of the calibration is to find realistic parameter values to illustrate the impact of adding local ties into an otherwise standard model of spatial equilibrium. So I mostly use parameters from the literature. But an obvious exception is the distribution of local ties, since I cannot rely on previous literature. To overcome this I use the method of simulated moments to match an empirical fact that I outlined above.

The target for the estimated distribution of local ties $(\mu)$ is the joint distribution of CZ level population changes from 1980 to 2008 and the share of people who were born locally in $2008 .{ }^{17}$ The inverse relationship of these two variables, shown in Figure 4, is what connects local ties to depressed areas. So it is important that the model be able to match it. Figure 6 shows both a scatter plot of the data and the relationship between these two variables in the model after a series of productivity draws that change the population of the affected area. ${ }^{18}$ The model matches the distribution.

I set the other parameters according to the literature. All of the relevant parameters are in Table 3. The spread of worker's idiosyncratic preferences for living in different places, $\sigma_{\xi}$, at 0.6 matches estimates in Suarez Serrato and Zidar (2016). The share of workers without any local ties matches the share of the US population

\footnotetext{
${ }^{16}$ Workers move without considering impacts on the local ties of future generations.

${ }^{17}$ I compute $\mu_{i}$ using Gaussian quadrature with 100 nodes per area.

${ }^{18}$ Changes in amenities lead to the same relationship, and the relationship does not depend on any parameters besides worker preferences.
} 
Figure 6: Estimation: Predicted and Observed Percentages Born Locally

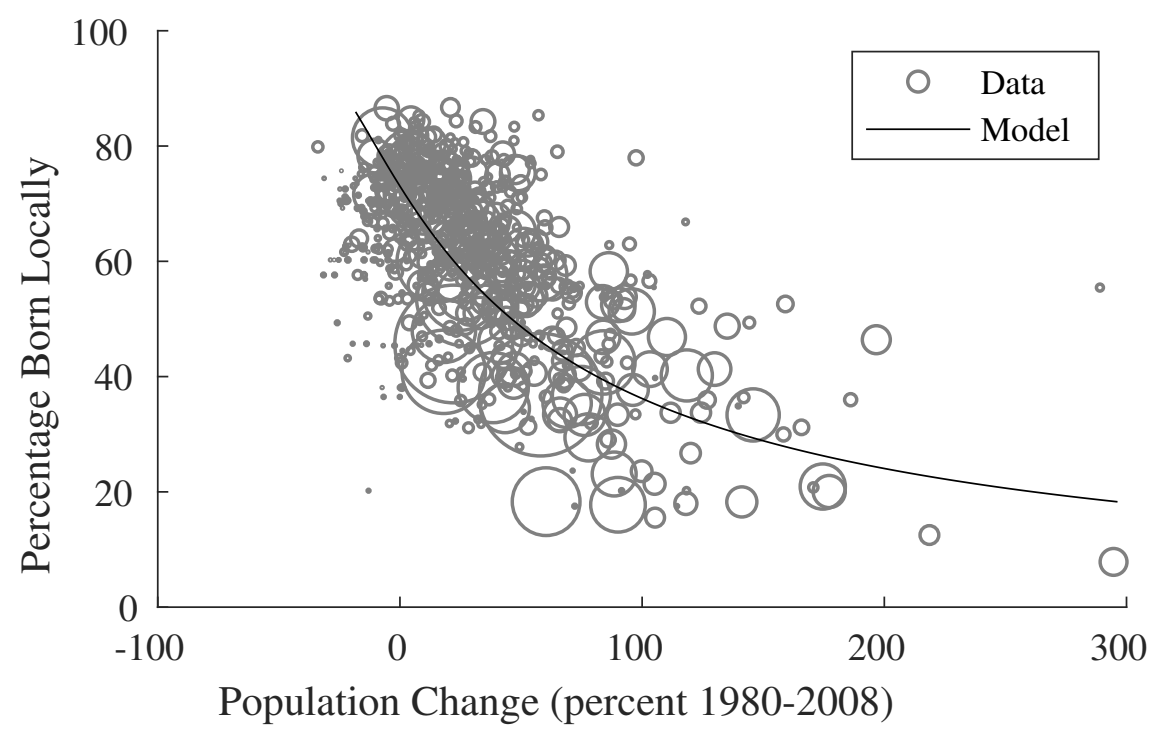

Note: I set the distribution of local ties $\left(\mu_{i}\right)$ to minimize the squared deviation with the joint distribution of population changes from 1980 to 2008 and the percent of residents born locally in the data. The line shows the relationship in the model and the circles show the observations in the data.

that was born outside the US. The share dying each year gives workers a 60 year lifespan, on average. The Armington elasticity $\left(\eta^{Y}\right)$ follows Feenstra et al. (2018), and the share of non-tradeable goods in consumption $\left(\alpha^{H}\right)$ matches consumption expenditure shares.

I assume a single, baseline set of local parameters governing productivity, amenities, and housing supply since my goal is distinct from understanding different levels of productivity, quality of life, geographic accessibility, and zoning. ${ }^{19}$ In practice, this means that I set the housing supply elasticity term $\left(\eta^{H}\right)$ to roughly the middle of the estimates in Saiz (2010) for all cities. I set all of the other local place specific terms to be identically equal to one, with the exception of productivity, which I shock in my quantitative exercises.

The model's estimated parameters allow it to approximate an un-targeted moment - the relationship between population changes and share of people born in a place

\footnotetext{
${ }^{19}$ Substantial literatures examine variations in all of these terms. For example, Rosen (1979), Roback (1982), Albouy (2016), and Diamond (2016) study variation in productivity and amenities.
} 
Table 3: Parameter Values

\begin{tabular}{clcl}
\hline Parameter & Description & Value & Reasoning \\
\hline$\mu_{\mu_{i}}$ & Mean local tie & 4.46 & Estimated \\
$\sigma_{\mu_{i}}$ & Variance of local ties & 5.52 & Estimated \\
$\sigma_{\xi}$ & Preference spread & 0.6 & Suarez Serrato and Zidar (2016) \\
$s_{F}$ & Share without ties & 0.13 & Share foreign born in US \\
$s_{D}$ & Share dying each year & 0.017 & 60 year average lifespan \\
$\eta^{Y}$ & Armington elasticity & 4 & Feenstra et al. (2018) \\
$\alpha^{H}$ & Non-tradeable share of cons & 0.33 & Expenditure shares \\
$\eta^{H}$ & Housing supply elasticity & 2 & Saiz (2010) \\
$\alpha^{Y}$ & Capital share & 0.33 & Standard \\
$\rho$ & Real interest rate & 0.05 & Standard \\
$J$ & Number of areas & 722 & Number of Commuting Zones \\
\hline
\end{tabular}

Note: The distribution of local ties was estimated based on the relationship between the share of locals in a commuting zone and changes in population from 1980 to 2008 - displayed in Figure 6. Otherwise model parameters match population moments and prior estimates.

who stay in it as adults. Figure 7 shows that the share of people who stay in a growing state is similar to the share who stay in a declining one and that the model predicts a slightly less modest relationship.

\section{Why There is Less Migration in Depressed Places}

The model both matches the fact that there are smaller migration responses in areas with higher local ties, and its structure gives an idea of why this should be the case. To see why there is less migration in places with higher local ties, consider the analytic formula for the percentage increase in population after an increase in real incomes $\left(\omega_{j}\right)$.

$$
\frac{\partial \ln \left(N_{j}\right)}{\partial \omega_{j}}=\frac{\left(1-\bar{\psi}_{j}\right)}{\sigma_{\xi}}
$$

The impact of a change in real incomes, holding all else constant, depends on a $\bar{\psi}_{j}$. Since $\bar{\psi}_{j}$ is the average level of attractiveness of the place relative to all other places for residents, it increases higher when people have higher levels of $\mu_{i}$. So 
Figure 7: Share of People Staying in Places: Model and Data

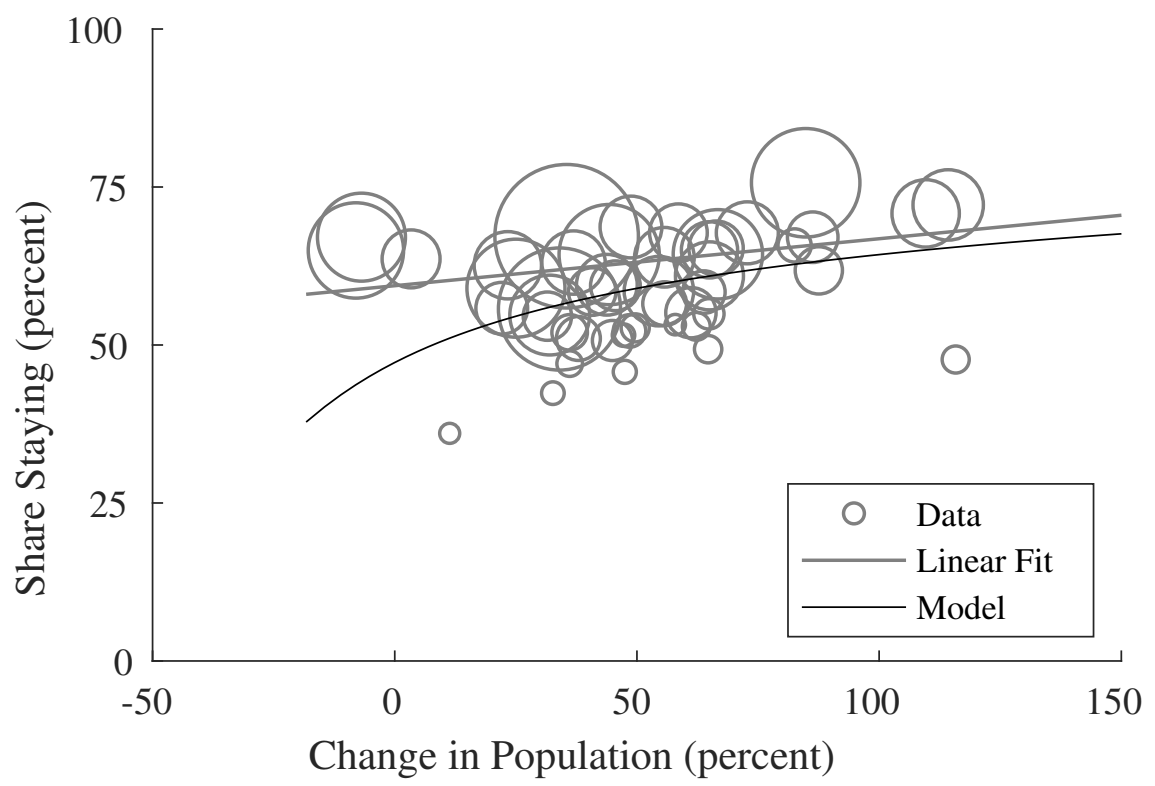

Note: The model approximates the share of people who stay in their state of birth when states experience various population changes. The black line shows the relationship among CZs in the model and the circles show the relationship among US states weighted by initial adult population, with the grey line of best fit. 
higher local ties imply lower migration elasticities. ${ }^{20}$

\section{Intuition}

The migration decisions of outsiders create low migration elasticities in depressed places. To show how outsiders can actually determine migration elasticities in high ties places I present a simplified version of the model with two areas and two types. The logit distribution allows me to show the exact relationship above. But the features of the logit distribution that lead to the result are common across many discrete choice probability distributions and the basic intuition extends to much more complex modeling strategies.

Consider a simplified world there are stayers who were born in a place and who always want to stay there, so $\psi_{S}=1$, and outsiders who were born elsewhere and who have no special affection for it, so $\psi_{O}<1$. For simplicity, assume that the probability has a logit distribution. The place that we are considering is small relative to the all of the places people could live, so there are ten times as many outsiders as stayers. ${ }^{21}$

The partial equilibrium effect of a change in real incomes on the likelihood that someone lives in a place $\left(\frac{\delta \psi_{i}}{\delta \omega}\right)$ is a function of their baseline likelihood of living there $\left(\psi_{i}\right)$ in the model. ${ }^{22}$ And the function peaks when the worker has an even likelihood of being there, as shown in Figure 8. So people are the most responsive to changes in places that they are actively considering against attractive alternatives.

Why does partial equilibrium effect of a change in real incomes vary with the baseline likelihood that someone lives in a place? The relationship is an important ingredient for taking a model of discrete choice to the data. Specifically, discrete choice probability distributions are $\mathrm{S}$ curves that have a linear portion in the middle and a low slopes at extreme values. The low slopes at extreme values allows the model to have an appropriate range and to include a minority of agents who make unusual choices (Train, 2009), as tends to happen empirically. The $\mathrm{S}$ shape is common across many discreet choice probability distributions - logit, probit, generalized extreme value, mixed logit, etc.

\footnotetext{
${ }^{20}$ Formally, $\bar{\psi}_{j}=\sum_{k^{\prime}} \sum_{i^{\prime}} \psi_{i^{\prime} j k^{\prime}} \frac{N_{i^{\prime} j k^{\prime}}}{N_{j}}$ where $\psi_{i j k}$ is defined in equation III.

${ }^{21} \mathrm{I}$ drop the implied $\mathrm{j}$ and $\mathrm{k}$ subscripts.
} 
So there are very low levels of migration by outsiders in places with high ties places with many stayers and few outsiders. Take a place where $3 / 4$ of residents are stayers in Figure 8. In the simplified model $\psi_{O}=1 / 90$ and so outsiders will be at the point labeled "Few Outsiders" and relatively unresponsive to increases in real incomes. Contrast this with a situation where $1 / 4$ of residents are stayers. Here, $\psi_{O}=1 / 10$ and outsiders are at the point labeled "Many Outsiders." Since $\psi_{O}$ is higher, outsiders are more responsive to changes in real incomes. The aggregate equation that I presented above emerges from aggregating the responses among both groups into a percentage change in population after a shock. Since the number of people in the place is equal to the number of each type times their probability of being in the place, the value is equal to an average of $\frac{1-\bar{\psi}_{i i}}{\sigma_{\xi}}$ where the weights are each type's share of the current population.

Figure 8: Migration Responses in the Simplified Model

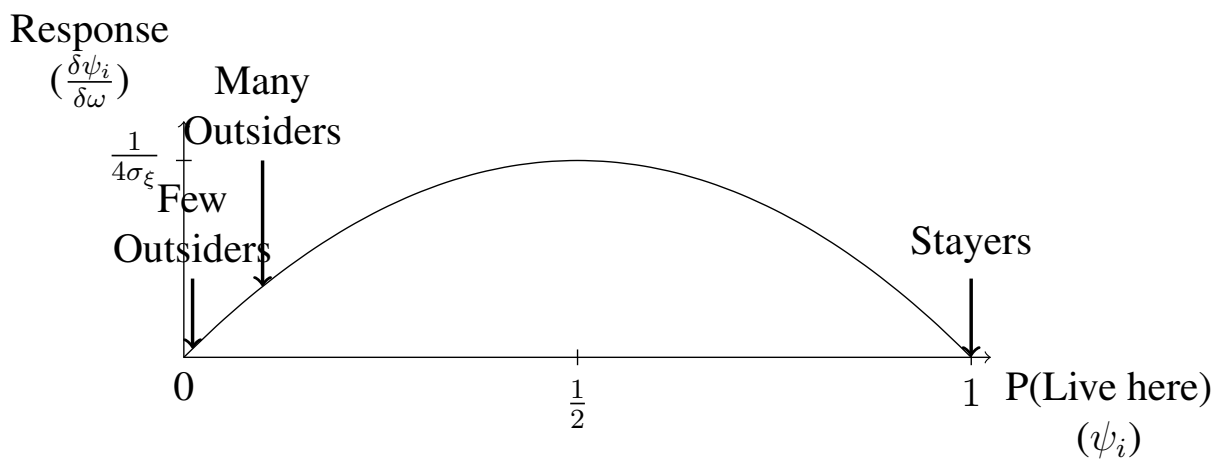

Note: Increases in desirability have a smaller impacts on outsiders' likelihood of living in the place $\left(\frac{d \psi_{i}}{d \omega}\right)$ in places where few outsiders live initially. The "Few Outsiders" gives outsiders' response when they make up $1 / 4$ of the population, and "Many Outsiders" gives it when they are $3 / 4$ of the population.

\section{Equilibrium Migration Responses}

The equilibrium elasticity of population with respect to nominal wages is the elasticity with respect to real incomes times a factor that depends on the housing market. The second factor represents how increases in housing costs impact Rosen and Roback style equilibrium. A less elastic housing supply will increase $\eta^{H}$ and $\alpha^{H}$ will be higher if people spend more on housing. Each will cause rent increases to 
be larger and each tends to lower the migration elasticity.

$$
\frac{d \ln \left(N_{j}\right)}{d \ln \left(w_{j}\right)}=\frac{\left(1-\bar{\psi}_{j}\right)}{\sigma_{\xi}} \times \frac{1+\eta^{H}-\alpha^{H}}{1+\eta^{H}+\alpha^{H}\left(1-\bar{\psi}_{j}\right) / \sigma_{\xi}}
$$

\section{Dynamics and Policy Implications}

The section shows the equilibrium dynamics and policy implications of local ties using the model developed in the last section. I show that local ties lead to hysteresis, that local ties change the cost and the benefits of place-based subsidies in subtle ways, and that local ties persist for generations.

\section{Hysteresis}

Declines in local productivity lead to hysteresis. Depressed places have residents with strong local ties, which keeps keeps population up and real incomes down in spatial equilibrium. And migration elasticities are lower in depressed places. So repeated negative shocks lead to successively larger real income declines.

Real incomes respond asymmetrically to changes in productivity. Panel A of Figure 9 shows real incomes on the $\mathrm{y}$-axis and changes in productivity on the $\mathrm{x}$ axis, along with a dotted line of best fit based on positive productivity shocks. The convexity of the solid line shows that negative productivity shocks lead to larger declines in real incomes than positive ones. And the larger changes in real incomes after negative productivity shocks is due to the changing share of locals, which produces the migration elasticities shown in Panel B. ${ }^{23}$

A history of negative shocks leads to smaller population responses and larger real income responses after new shocks. Figure 10 plots the impact of two successive fifty percent declines in productivity - Panel A. Each shock changes the share of locals in the area - Panel B - and the changing levels of residents' local ties changes equilibrium responses.

Real incomes decline by more and population by less after the second shock. Panels C and D of Figure 10 show real income and population responses. The initial

\footnotetext{
${ }^{23}$ Dao, Furceri and Loungani (2017) find similar asymmetric responses.
} 
Figure 9: Real Incomes and Migration Elasticities after Productivity Changes

Panel A: Real Incomes

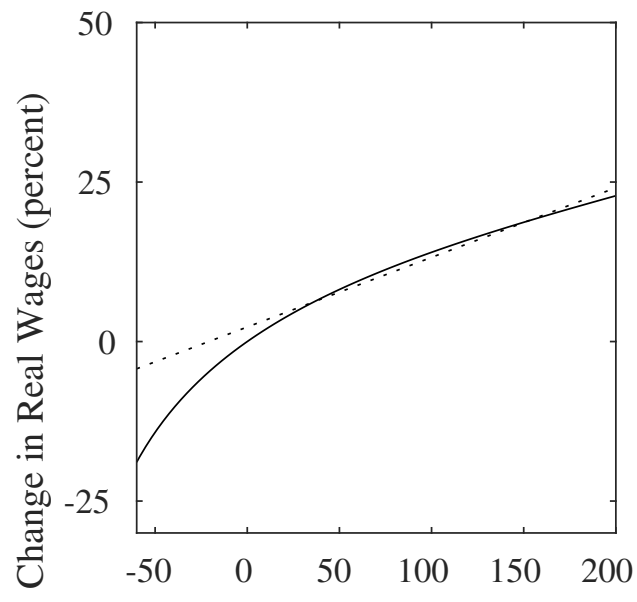

Change in Productivity (percent)
Panel B: Migration Elasticity

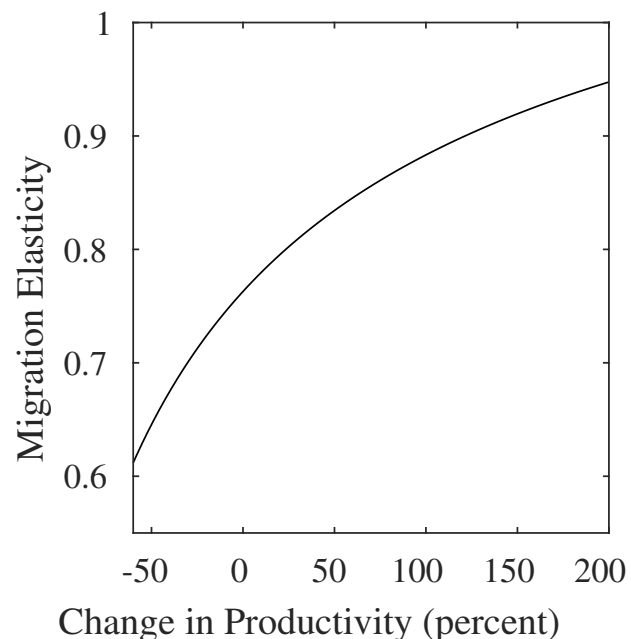

Note: Positive productivity shocks lead to smaller changes in real incomes because migration elasticities increase with positive productivity shocks.

shock involves a real income decline of about 19 percentage points and a population decline of around 35 percentage points. The second shock changes productivity by the same percentage, but leads to a 27 percent larger decline in real incomes and a 14 percent smaller decline in population.

\section{Place-Based Subsidies}

Many governmental programs subsidize some places at the expense of others, either explicitly or implicitly. For example, place-based policies induce place-based subsidies in when they improve outcomes in one place based on revenues raised from other places. ${ }^{24}$ Concerns about inequality across places have led to renewed interest in place-based policies (Neumark and Simpson, 2015; Austin, Glaeser and Summers, 2018). A common criticism, however, is that subsidizing one area the expense of another leads to population distortions. But the dynamics of residents' higher levels of local ties in depressed places, and of smaller movements to productive places because of people's local ties, make these criticisms less empirically 
Figure 10: Responses after Two Negative Productivity Shocks
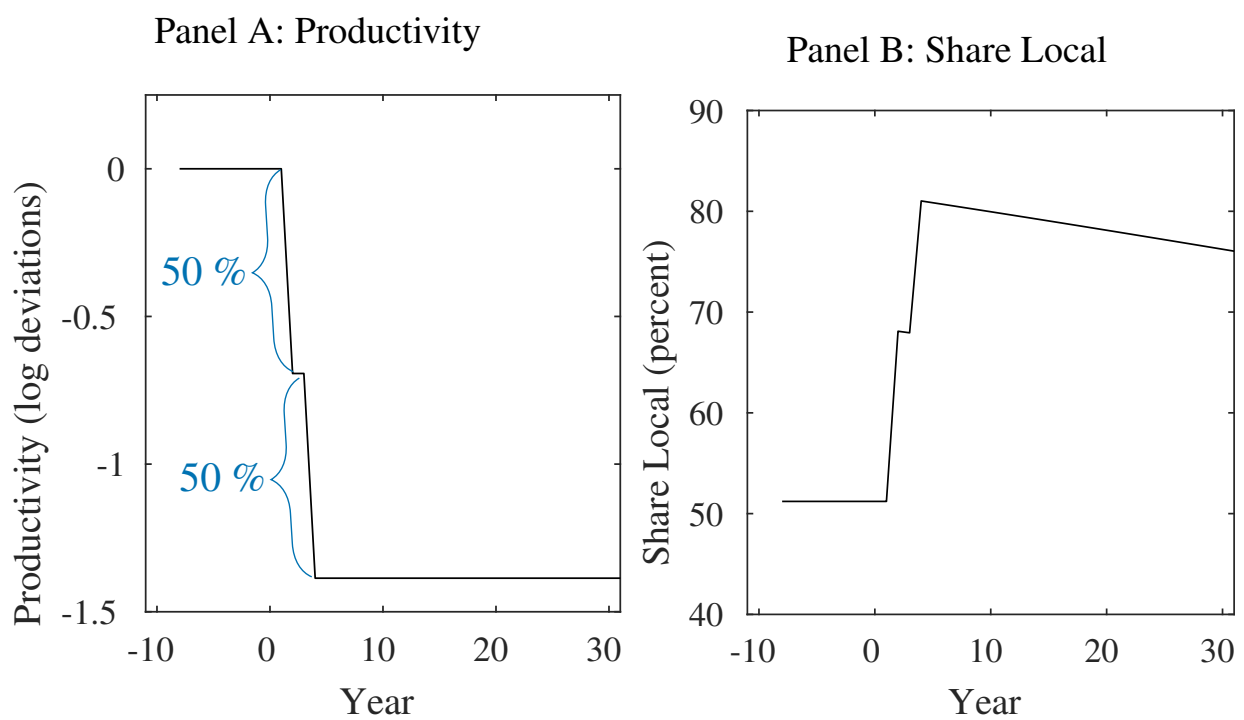

Panel C: Real Income
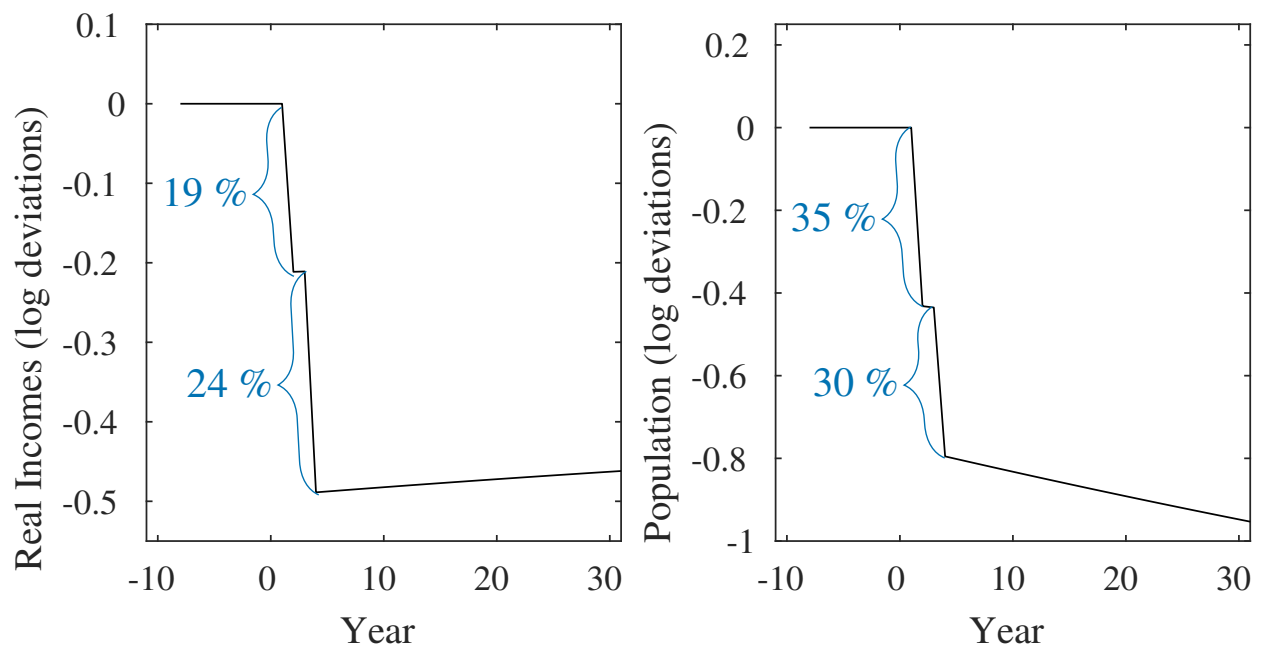

Note: Real incomes decline by more and population declines by less and after a second 50 percent decline in local productivity. Shown is the equilibrium response of the specified variables after the noted change in productivity in an area. The blue labels give the percent changes for variables reported in logs. 
relevant.

The dynamics of local ties imply that subsidies to depressed places, where most residents have local ties, will lead to smaller distortions, decreasing their cost. Instead, subsidies to depressed places transfer money to people who would have lived in the same place without the subsidy. Only a small amount goes to paying for people to move in, since people who lack local ties are reluctant to live in depressed places.

Local ties also imply that subsidies to growing, newly productive places will lead more people to move to productive areas, increasing their benefits for aggregate productivity. The larger migration elasticities in growing, low ties places lead to larger population responses. And population reallocations to productive places increases wages in other places, particularly in the medium run.

To show how local ties affect the benefits and costs of place-based subsidies, I show the impacts of subsidies to places with varying levels of local ties. I model a per worker subsidy equal to ten percent of initial wages, paid by negative subsidies in other areas. I assume that the subsidy declines by four percent per year (as in Kline and Moretti, 2014a). So the subsidy is a 1.3 percentage points of initial wages after 50 years and a 0.2 after 100 .

I use two metrics based on changes in real incomes net of taxes $(\omega)$. The first is the ratio of percent changes in real incomes per capita to percent changes in population in the subsidized area. The ratio of changes in incomes and populations highlights the trade off between increasing the utility of residents and increasing local population, which Kline and Moretti (2014b) and Zabek (2018) show is a sufficient statistic for decreases in aggregate utility in standard models of spatial equilibrium. The second metric is the change in per capita real incomes, net of taxes. Plotting changes in per capital real incomes is theoretically less elegant, but it shows the trade off between the incomes of people in different places more

\footnotetext{
${ }^{24}$ Place-based policies have taken many different forms. Some have included grants and tax benefits targeted at particular communities (empowerment and opportunity zones, Busso, Gregory and Kline (2013)). Others have increased funding for local schools or paid residents' college tuition (promise programs, Bartik, Hershbein and Lachowska (2019)). Others have included state and local tax incentives designed to attract particular companies (e.g. packages from many cities designed to attract Amazon's second headquarters). Some policies have led to place-based subsidies more indirectly, like the use of nominal prices in the federal tax and transfer system (Albouy, 2009)).
} 
directly. ${ }^{25}$

Subsidies to depressed places where residents have stronger local ties can lower geographic inequality at a lower cost to aggregate productivity because they increase real incomes without much population distortion. Panel A of Figure 11 shows that the impact on real incomes relative to population increases (at an increasing rate) with higher levels of local ties. Subsidizing a place with 60 percent of its population born locally, like Minneapolis, leads to a slightly less than onehalf percentage point increase in real incomes for every percentage point increase in population. And subsidizing a place where around 80 percent of the population was born locally, like Dayton, Buffalo, or Pittsburgh, leads to a one percentage point increase in population for each percent point increase in real wages. ${ }^{26}$ Panel B shows a similar story. Real wages in subsidized places with high levels of local ties increase with local ties. The real wage impacts on other areas are mostly flat with respect to local ties in the subsidized area. So subsidies to depressed places where residents have strong local ties lead to higher local incomes with low costs in aggregate productivity and real incomes in other places.

Subsidies to productive places where residents lack local ties move more people to productive places, which increases aggregate productivity and real wages in other places. Since subsidies to places with low ties increase population by more than incomes, as shown in Panel A, they have larger impacts on aggregate productivity through labor reallocation. So much so that subsidies to productive places can increase real incomes in places that pay for them, as shown in Panel B. Subsidies to places where less than around 45 percent of residents were born locally lead to increases in real incomes in other places. So, subsidizing cities where low shares of the population were born locally - like Dallas, Los Angeles, Atlanta, and Houston can benefit workers in other places, despite having to pay for the subsidies through higher taxes. ${ }^{27}$

Real incomes increase other places because of real wages increases that result

\footnotetext{
${ }^{25}$ Note that I scale the effect on real incomes in other places by multiplying by their number (721 in this calibration).

${ }^{26}$ Examples are based on Table A.2, which represent values in the relevant Commuting Zones in 2008.

${ }^{27}$ Subsidies do not generally lead to pareto improvements, however.
} 
Figure 11: Real Income Changes after Place-Based Subsidies

\section{Panel A: Ratio of Incomes to Populations}
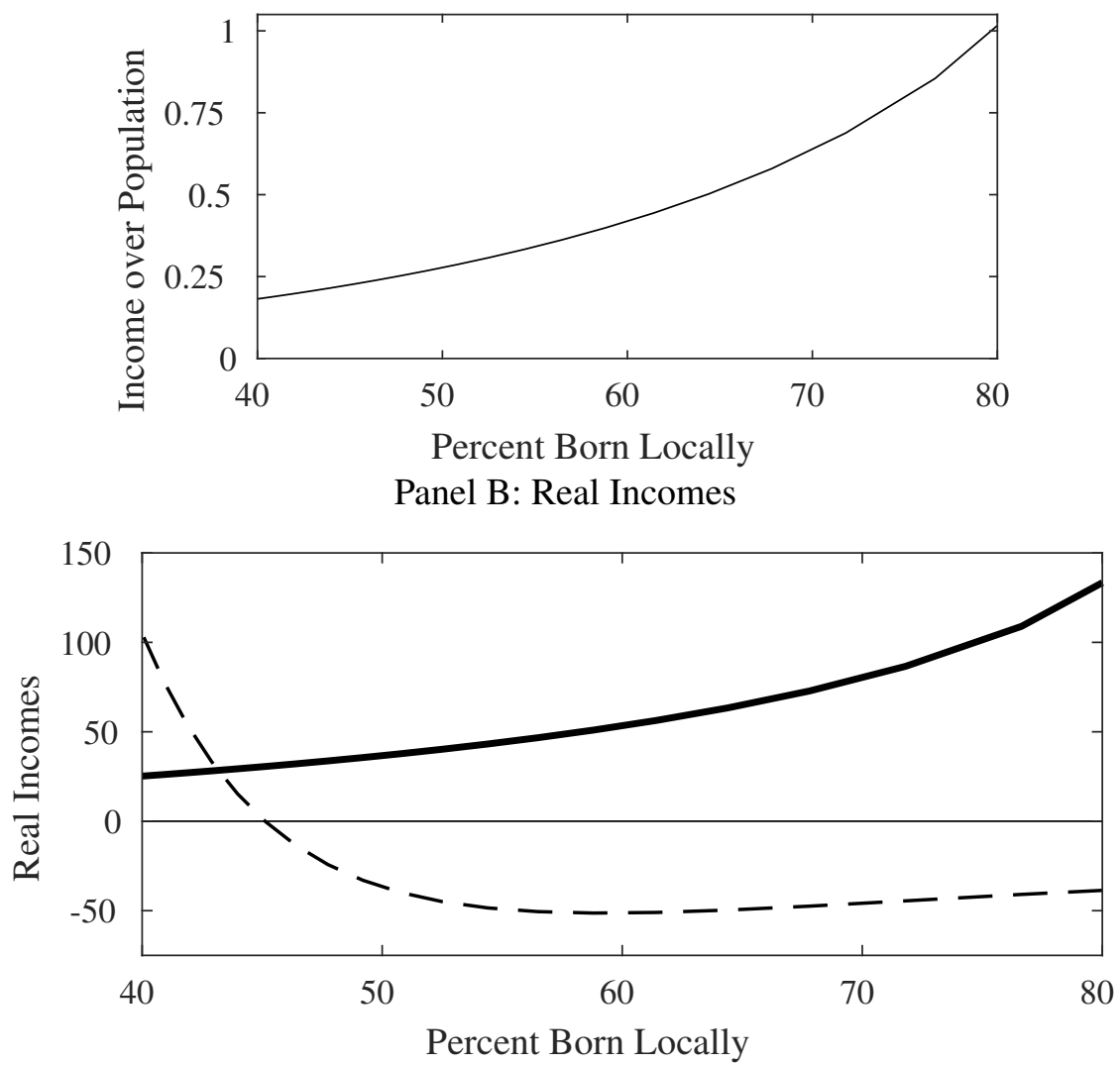

\section{Subsidized Place $\quad-\quad-$ Other Places}

Note: Subsidies to economically depressed places where most residents were born locally increase real incomes by more relative to population. And subsidies to newly productive places with low levels of local ties increase wages in other places. Panel A plots the ratio of the present discounted values of percentage changes in local real incomes relative to population after a subsidy. The bottom panel plots the present discounted value of changes in real incomes per worker $(\omega)$ after the subsidy. The subsidy is initially equal to 10 percent of initial wages in an area with no productivity shock, and it decays at four percent per years. Real incomes include wages net of taxes as well as rents. The line for other areas is multiplied by the number of other areas, which is 721 in this calibration. 
from reductions in local labor supply and increases in aggregate productivity from people moving to a more productive place. Labor supply decreases in other places push up wages (Hornbeck and Moretti, 2018). And movement into a productive place increases aggregate productivity. Since modest subsidies to productive places lead many people to move, the wage benefits to other places can outweigh the cost of the subsidy in terms of increased taxes, as shown in Panel B of Figure 11.

Subsidies to productive places also counteract the externality of parents making migration decisions based on their local ties and not their children's. Children benefit when their parents move to places that are more productive, since children develop ties to places with higher real wages. So subsidies counteract the externality by paying parents to move to productive places.

Subsidies to productive places also speed convergence and lead to larger long run population increases because more children stay in productive areas. Table 4 shows the impacts of subsidies on populations and on real incomes initially, after 50 years, and after 100 years. On impact, the subsidy increases population by around 6.5 percentage points in most places. After 50 and 100 years the impacts on population are smaller in all areas, but in relative terms they are more dramatic in low ties places. The persistent effects on population also mean that subsidies to productive places have more persistent impacts on real incomes in other places.

Table 4: Effects of Subsidies to Depressed and to Growing Places

\begin{tabular}{ccccccccccc}
\hline & \multicolumn{4}{c}{ Subsidized Place } & \multicolumn{3}{c}{ Other Places } \\
Share & \multicolumn{3}{c}{ Population } & \multicolumn{3}{c}{ Real Incomes } & \multicolumn{3}{c}{ Real Incomes } \\
Locals & 0 & 50 & 100 & 0 & 50 & 100 & 0 & 50 & 100 \\
\hline 40 & 6.6 & 1.6 & 0.7 & 1.6 & 0.2 & -0.0 & 4.1 & 1.6 & 0.8 \\
50 & 6.4 & 1.5 & 0.6 & 2.3 & 0.2 & -0.0 & -2.5 & -0.2 & 0.0 \\
60 & 6.3 & 1.4 & 0.6 & 3.3 & 0.3 & -0.0 & -3.1 & -0.4 & -0.1 \\
70 & 6.4 & 1.3 & 0.5 & 4.9 & 0.5 & -0.0 & -2.8 & -0.4 & -0.1 \\
80 & 6.9 & 1.3 & 0.4 & 7.9 & 0.9 & 0.0 & -2.5 & -0.3 & -0.1 \\
\hline
\end{tabular}

Note: Subsidies to growing places with low shares of locals speed long term convergence. The table shows percent changes in populations and real incomes for the subsidized place and others places after the same size subsidies depicted in Figure 11. See the notes on that figure for more details. 


\section{Persistence}

Local ties are persistent. Table 5 shows that population and real incomes are still evolving nearly fifty years after a change in productivity. The first column of the table shows the size of the initial shock the productivity - positive or negative. The second through sixth columns show the initial percentage change in population, the change in population after fifty years, the change after 100 years, and the half life of population in terms of its deviation from steady state. The following columns show the same process for real incomes in the model $(\omega)$.

Convergence is quite slow regardless of the size of the productivity shock. The 50 percent decline in productivity in the first row of Table 5 leads to a 28 percentage point initial decline in population. The initial decline is only about 63 percent of the total decline of 45 percent, however. After 50 years - almost a generation in this calibration - population has declined by an additional seven percentage points, but it still has to fall by another ten to reach its steady state. Slow convergence is apparent in all rows, though it scaled by magnitude of the productivity changes.

Table 5: Convergence After Productivity Changes

\begin{tabular}{ccccccccccc}
\hline $\begin{array}{c}\text { Productivity } \\
\text { change }\end{array}$ & Initial & 50 & 100 & SS & HL & Initial & 50 & 100 & SS & HL \\
\hline-50 & -28.3 & -35.2 & -39.2 & -45.0 & 65 & -14.2 & -13.2 & -12.5 & -11.5 & 65 \\
-25 & -13.4 & -16.8 & -18.9 & -22.0 & 67 & -5.8 & -5.4 & -5.2 & -4.8 & 67 \\
-10 & -5.2 & -6.6 & -7.4 & -8.7 & 67 & -2.1 & -2.0 & -1.9 & -1.8 & 67 \\
-5 & -2.6 & -3.3 & -3.7 & -4.3 & 67 & -1.0 & -1.0 & -0.9 & -0.9 & 67 \\
50 & 24.3 & 31.0 & 35.2 & 41.9 & 72 & 8.2 & 7.6 & 7.3 & 6.8 & 72 \\
\hline
\end{tabular}

Note: Convergence is slow after productivity changes. Populations under shoot and real wages overshoot their steady state values. The table plots responses to a permanent change in local productivity over time. The first column shows the change in productivity. The next five columns show the population response with the second showing the initial percentage change, the third the percentage change after fifty years, the fourth after 100 years, and the fifth showing the time it takes for the gap between the initial and the steady state value to halve. The next five columns show the same values for real incomes, $\omega$.

Real incomes overshoot their steady state values and recover slowly. Table 5 shows that real incomes initially drop by 14 percentage points after the same 50 percent decline in productivity - about one quarter more than their steady state value. Even after fifty years, real incomes are about two percentage points lower 
than their eventual steady state.

The convergence process is slow because it takes generations for local ties to be reallocated. After a decrease in productivity, population falls due to the fall in real incomes. Since people still have local ties, however, the change in population is smaller than the change in steady state. The smaller population response leads to the overshooting in real incomes. Low real incomes keep people moving out of the area each generation, however, so local ties decline with each generation. The very gradual downward slope of the line at the end of Panel C in Figure 10 highlights how slowly these local ties change, however. ${ }^{28}$

\section{Conclusion}

Local ties keep people in economically depressed places, and people who live in economically depressed places are most often born there. Economically depressed places where residents have local ties also have depressed real wages that are more volatile. And local ties persist for generations.

Including local ties in spatial equilibrium implies that place-based subsidies can be efficacious. In depressed places, place-based subsidies lead to small population changes. So they transfer income without distorting where people live. In productive places, place-based subsidies increase aggregate productivity and wages by changing where people live. Place-based subsidies in growing places also lead more workers to form ties in productive areas.

Several phenomena could lead to local ties. Local ties could be due to the presence of family members and friends (Kaplan, 2012; Kramarz and Skans, 2014; Coate, Krolikowski and Zabek, 2019) or job referral networks (Topa, 2011). It would be useful to quantify how much of people's local ties can be related to these phenomena and how unchanging local ties are in the face of various interventions.

More knowledge of local ties could inform policy responses that shape how people form local ties. Social networks could be transportable if local conditions become particularly unfavorable (Yannay Spitzer, 2015), governments could provide loans to encourage mobility, and certain interventions could address information

\footnotetext{
${ }^{28}$ Real incomes never fully recover because of the distribution of $\xi$.
} 
frictions (Wilson, 2016). Recognizing heterogeneity in residents' local ties could also inform policies so that they balance the benefits of population reallocation with the reality that most people live close to their birthplaces.

\section{References}

Albert, Christoph, and Joan Monras. 2018. "Immigration and Spatial Equilibrium: The Role of Expenditures in the Country of Origin." CEPR Discussion Paper 12842. CEPR Discussion Paper No. DP12842.

Albouy, David. 2009. "The Unequal Geographic Burden of Federal Taxation." Journal of Political Economy, 117(4): 635-667.

Albouy, David. 2016. "What are cities worth? Land rents, local productivity, and the total value of amenities." The Review of Economics and Statistics, 98(3): 477487.

Austin, Benjamin, Edward Glaeser, and Lawrence Summers. 2018. "Jobs for the Heartland: Place-Based Policies in 21st-Century America." Brookings Papers on Economic Activity, 49(1): 151-255.

Autor, David, David Dorn, and Gordon Hanson. 2013. "The China Syndrome: Local Labor Market Effects of Import Competition in the United States." American Economic Review, 103(6): 2121-2168.

Bartik, Timothy. 1991. "Who Benefits from State and Local Economic Development Policies?" W.E. Upjohn Institute for Employment Research, Kalamazoo, MI:W.E. Upjohn Institute for Employment Research.

Bartik, Timothy. 2009. "What proportion of children stay in the same location as adults, and how does this vary across location and groups?" W.E. Upjohn Institute for Employment Research Upjohn Institute Working Paper 09-145.

Bartik, Timothy J., Brad Hershbein, and Marta Lachowska. 2019. "The Effects of the Kalamazoo Promise Scholarship on College Enrollment and Completion." Journal of Human Resources.

Beaudry, Paul, David A. Green, and Benjamin M. Sand. 2014. "Spatial equilibrium with unemployment and wage bargaining: Theory and estimation." Journal of Urban Economics, 79: 2 - 19. Spatial Dimensions of Labor Markets. 
Bilal, Adrien, and Esteban Rossi-Hansberg. 2018. "Location as an Asset." National Bureau of Economic Research Working Paper 24867.

Black, Dan A., Seth G. Sanders, Evan J. Taylor, and Lowell J. Taylor. 2015. "The Impact of the Great Migration on Mortality of African Americans: Evidence from the Deep South.” American Economic Review, 105(2): 477-503.

Blanchard, Olivier, and Lawrence Katz. 1992. "Regional evolutions.” Brookings Papers on Economic Activity, 23(1): 1-73.

Borusyak, Kirill, Peter Hull, and Xavier Jaravel. 2018. "Quasi-Experimental Shift-Share Research Designs." National Bureau of Economic Research Working Paper 24997.

Bound, John, and Harry J Holzer. 2000. "Demand Shifts, Population Adjustments, and Labor Market Outcomes during the 1980s." Journal of Labor Economics, 18(1): 20-54.

Busso, Matias, Jesse Gregory, and Patrick Kline. 2013. "Assessing the Incidence and Efficiency of a Prominent Place Based Policy." American Economic Review, 103(2): 897-947.

Cadena, Brian C., and Brian K. Kovak. 2016. "Immigrants equilibrate local labor markets: Evidence from the great recession." American Economic Journal: Applied Economics, 8(1): 257-290.

Chetty, Raj, and Nathaniel Hendren. 2018. "The Impacts of Neighborhoods on Intergenerational Mobility II: County-Level Estimates*." The Quarterly Journal of Economics, 133(3): 1163-1228.

Chiara Criscuolo, Martin Ralf, Henry G Overman, and John Van Reenen. 2019. "Some Causal Effects of an Industrial Policy." American Economic Review, 109(1): 48-85.

Coate, Patrick, Pawel Michal Krolikowski, and Mike Zabek. 2019. "Parental Proximity and Earnings after Job Displacements." Finance and Economics Discussion Series 2019-062.2. Washington: Board of Governors of the Federal Reserve System, https://doi.org/10.17016/FEDS.2019.062.

Coen-Pirani, Daniele. 2010. "Understanding gross worker flows across U.S. states." Journal of Monetary Economics, 57: 769-784. 
Dao, Mai, Davide Furceri, and Prakash Loungani. 2017. "Regional Labor Market Adjustment in the United States: Trend and Cycle." The Review of Economics and Statistics, 99(2): 243-257.

Davis, Morris A., Jonas D. M. Fisher, and Marcelo Veracierto. 2013. "Gross Migration, Housing and Urban Population Dynamics." Federal Reserve Bank of Chicago Federal Reserve Bank of Chicago Working Paper 2013-19.

Diamond, Rebecca. 2016. "The Determinants and Welfare Implications of US Workers' Diverging Location Choices by Skill: 1980-2000." American Economic Review, 106(3): 479-524.

Feenstra, Robert C., Philip Luck, Maurice Obstfeld, and Katheryn N. Russ. 2018. "In Search of the Armington Elasticity." The Review of Economics and Statistics, 100(1): 135-150.

Fu, Chao, and Jesse Gregory. 2018. "Estimation of an Equilibrium Model with Externalities: Post-Disaster Neighborhood Rebuilding." Econometrica.

Gabaix, Xavier. 1999. “Zipf's law for cities: an explanation.” The Quarterly Journal of Economics, 114(3): 739-767.

Ganong, Peter, and Daniel Shoag. 2017. "Why has regional income convergence in the U.S. declined?" Journal of Urban Economics.

Glaeser, Edward, and Joseph Gyourko. 2005. "Urban Decline and Durable Housing." Journal of Political Economy, 113(2): 345-000.

Glaeser, Edward, and Joshua Gottlieb. 2008. "The Economics of Place-Making Policies.” Brookings Papers on Economic Activity, 2008(1): 155-253.

Goldsmith-Pinkham, Paul, Isaac Sorkin, and Henry Swift. 2018. "Bartik Instruments: What, When, Why, and How." National Bureau of Economic Research Working Paper 24408.

Green, David, Rene Morissette, and Benjamin M. Sand. 2017. "Economy Wide Spillovers From Booms: Long Distance Commuting and the Spread of Wage Effects." Vancouver School of Economics Microeconomics.ca working papers 2017-7.

Gregory, Jesse. 2013. "The Impact of Post-Katrina Rebuilding Grants on the Resettlement Choices of New Orleans Homeowners." Unpublished manuscript. 
Hornbeck, Richard, and Enrico Moretti. 2018. "Who Benefits From Productivity Growth? Direct and Indirect Effects of Local TFP Growth on Wages, Rents, and Inequality." National Bureau of Economic Research Working Paper 24661.

Hsieh, Chang-Tai, and Enrico Moretti. 2015. "Housing Constraints and Spatial Misallocation.” National Bureau of Economic Research Working Paper 21154.

Huttunen, Kristiina, Jarle Møen, and Kjell G Salvanes. 2018. "Job Loss and Regional Mobility.” Journal of Labor Economics, 36(2): 479-509.

Kaplan, Greg. 2012. "Moving Back Home: Insurance against Labor Market Risk." Journal of Political Economy, 120(3): 446-512.

Kearney, Melissa S, and Phillip B Levine. 2015. "Early Childhood Education by MOOC: Lessons from Sesame Street." National Bureau of Economic Research Working Paper 21229.

Kennan, John, and James Walker. 2011. "The Effect of Expected Income on Individual Migration Decisions." Econometrica, 79(1): 211-251.

Kline, Patrick, and Enrico Moretti. 2013. "Place based policies with unemployment." American Economic Review, 103(3): 238-243.

Kline, Patrick, and Enrico Moretti. 2014a. "Local Economic Development, Agglomeration Economies, and the Big Push: 100 Years of Evidence from the Tennessee Valley Authority." The Quarterly Journal of Economics, 129(1): 275-331.

Kline, Patrick, and Enrico Moretti. 2014b. "People, Places and Public Policy: Some Simple Welfare Economics of Local Economic Development Programs." Annual Review of Economics, 6: 629-62.

Kramarz, Francis, and Oskar Nordström Skans. 2014. "When Strong Ties Are Strong: Family Networks and Youth Labor Market Entry." Review of Economic Studies, 81(3): 1164-1200.

Mangum, Kyle, and Patrick Coate. 2018. "Fast Locations and Slowing Labor Mobility." Andrew Young School of Policy Studies Research Paper Series No. 18-05 March.

Manning, Alan, and Barbara Petrongolo. 2017. "How Local Are Labor Markets? Evidence from a Spatial Job Search Model." American Economic Review, 107(10): 2877-2907. 
Monras, Joan. 2015. "Economic Shocks and Internal Migration.” IZA Institute of Labor Economics Discussion Paper No. 8840.

Munshi, Kaivan. 2003. "Networks in the Modern Economy: Mexican Migrants in the U. S. Labor Market.” The Quarterly Journal of Economics, 118(2): 549-599.

Nakamura, Emi, Josef Sigurdsson, and Jon Steinsson. 2016. "The Gift of Moving: Intergenerational Consequences of a Mobility Shock." National Bureau of Economic Research Working Paper 22392.

Neumark, David, and Helen Simpson. 2015. "Place-Based Policies." In Handbook of Regional and Urban Economics. Vol. 5, 1197-1287. Elsevier.

Notowidigdo, MJ. 2011. "The incidence of local labor demand shocks." National Bureau of Economic Research Working Paper 17167.

Rappaport, Jordan. 2004. "Why are population flows so persistent?" Journal of Urban Economics, 56(3): 554-580.

Redding, Stephen J, and Esteban Rossi-Hansberg. 2017. "Quantitative spatial economics." Annual Review of Economics, 9: 21-58.

Roback, Jennifer. 1982. "Wages, rents, and the quality of life." The Journal of Political Economy, 90(6): 1257-1278.

Rosen, Sherwin. 1979. "Wage-based indexes of urban quality of life." In Current Issues in Urban Economics., ed. Mahlon Straszheim and Peter Mieszkowski. Baltimore, MD:Johns Hopkins University Press.

Ruggles, Steven, J. Trent Alexander, Katie Genadek, Ronald Goeken, Matthew B. Schroeder, and Matthew Sobek. 2010. "Integrated Public Use Microdata Series: Version 5.0."

Saiz, Albert. 2010. "The geographic determinants of housing supply." The Quarterly Journal of Economics, 125(3): 1253-1296.

Shoag, Daniel, and Nicholas Carollo. 2016. "The Causal Effect of Place: Evidence from Japanese-American Internment." Harvard University, John F. Kennedy School of Government Working Paper Series 16-022.

Stuart, Bryan A. 2017. "The Long-Run Effects of Recessions on Education and Income.” Center for Economic Studies, U.S. Census Bureau Working Papers 1752. 
Stuart, Bryan A. 2018. "The Long-Run Effects of Recessions on Education and Income." 'Unpublished Manuscript: George Washington University'.

Suarez Serrato, Juan Carlos, and Owen Zidar. 2016. "Who benefits from state corporate tax cuts? A local labor markets approach with heterogeneous firms." American Economic Review, 106(9): 2582-2624.

Tolbert, Charles M., and Molly Sizer. 1996. "U.S. Commuting Zones and Labor Market Areas: A 1990 Update.” Rural Economy Division, Economic Research service, U.S. Department of Agriculture Staff Paper AGES-9614, Washington, DC.

Topa, Giorgio. 2011. "Labor markets and referrals." Handbook of Social Economics, 1(1 B): 1193-1221.

Train, Kenneth E. 2009. Discrete choice methods with simulation. . Second ed., New York:Cambridge University Press.

Wilson, Riley. 2016. "Moving to Economic Opportunity: The Migration Response to the Fracking Boom." Available at SSRN: https://ssrn.com/abstract=2814147 or https://dx.doi.org/10.2139/ssrn.2814147.

Yagan, Danny. 2017. "Employment Hysteresis from the Great Recession." National Bureau of Economic Research Working Paper 23844.

Yannay Spitzer. 2015. “The Dynamics of Mass Movements." Unpublished manuscript.

Zabek, Mike. 2018. "Essays on Places and Economic Inequality.” PhD diss. University of Michigan. 